\title{
顔の再認におけるジェンダーバイアスの生起メカニズムの検討
}

一倒立効果パラダイムを用いた知覚的熟達要因の検討 一

北神慎司 ${ }^{1} \cdot$ 中嶋智史 ${ }^{2,3}$

( ${ }^{1}$ 名古屋大学大学院環境学研究科・ ${ }^{2}$ NTT コミュニケーション科学基礎研究所・ ${ }^{3}$ 科学技術振興機構 CREST) キーワード : 顔の再認, ジェンダーバイアス, 倒立効果

\section{Own-gender bias and the effect of inversion on face recognition}

Shinji KITAGAMI ${ }^{1}$ and Satoshi NAKASHIMA ${ }^{2}$

$\left({ }^{1}\right.$ Graduate School of Environmental Studies, Nagoya University, ${ }^{2}$ NTT Communication Science Laboratories, ${ }^{3}$ CREST, JST)

Key Words: face recognition, own-gender bias, inversion effect

\section{目 的}

人種バイアス (own-race bias) と同じく，顔の認識や記憶に おける一種の集団バイアス（own-group bias）として，近年， ジェンダーバイアス (own-gender bias) という現象が報告され ている。これは，異性の顔よりも同性の顔のほうが認識しや すく記憶しやすいという現象であるが，先行研究間で結果の パターンが一貫していないだけでなく，その生起メカニズム についても十分な検討がなされているとは言えない.

そこで, 本研究では, 倒立効果のパラダイムを用いて集団 バイアスにおける知覚的熟達要因の関与を検討した Rhodes et al. (1989), Kuefner et al. (2008)の実験操作を援用して, 顔の再 認におけるジェンダーバイアスの生起に知覚的熟達要因が関 与するかどうかを検討した，仮説としては，人種の場合とは 異なり, 同性と異性とで接触経験が大きく異なる（たとえば, 同性の方が接触経験が多い，あるいは，異性の方が接触経験 が多い）とは考えにくいため，倒立顔においてもジェンダー バイアスは生じる, つまり, その生起に知覚的熟達要因は関 与していないと考えられる.

\section{方 法}

参加者: 大学生 153 名（男性 59 名, 女性 94 名）が参加した. デザイン：参加者の性別（男性・女性） ×顔刺激の性別（男 性・女性） ×顔刺激の向き（正立顔・倒立顔）の 3 要因混合 計画であった。

刺激 : 実験参加者と同世代の男女各 32 名の正立顔および倒立 顔の写真 (グレースケール). 刺激の半数は, 再認記憶課題に おいてディストラクタとして使用した.

手続き: 学習セッションにおいて, 意図学習教示のもと, 計 32 枚（男性・正立, 男性・倒立, 女性・正立, 女性・倒立で, 1 条件あたり 8 試行)のターゲットが 1 枚につき $2000 \mathrm{msec}$ (ISI は $1000 \mathrm{msec}$ ）提示され，5分間の妨害課題の後, 計 32 枚のデ イストラクタをターゲットに追加して, old/new 判断形式の再 認記憶課題が行われた.

表 1 条件ごとの各記憶指標の平均 $(S D)$

\begin{tabular}{llllll}
\hline & & \multicolumn{2}{c}{ 男性参加者 } & \multicolumn{2}{c}{ 女性参加者 } \\
& & 男性顔 & 女性顔 & 男性顔 & 女性顔 \\
\hline \multirow{2}{*}{ Hit 率 } & 正立顔 & $.59(.20)$ & $.57(.19)$ & $.57(.19)$ & $.60(.19)$ \\
& 倒立顔 & $.61(.18)$ & $.55(.20)$ & $.55(.16)$ & $.57(.20)$ \\
\hline \multirow{2}{*}{ FA 率 } & 正立顔 & $.22(.20)$ & $.22(.16)$ & $.16(.15)$ & $.20(.15)$ \\
& 倒立顔 & $.41(.17)$ & $.36(.22)$ & $.35(.18)$ & $.32(.21)$ \\
\hline \multirow{2}{*}{$A$} & 正立顔 & $.76(.15)$ & $.76(.12)$ & $.79(.11)$ & $.79(.11)$ \\
& 倒立顔 & $.70(.11)$ & $67(.13)$ & $.69(.11)$ & $.73(.12)$ \\
& & & & &
\end{tabular}

結 果

3 要因分散分析の主要な結果を以下に示す.

まず, hit率については，参加者の性別×顔刺激の性別の交 互作用が有意であったため $(F(1,151)=4.85, p=.029)$, 下位検 定を行った結果，男性参加者における顔刺激の性別の単純主 効果が有意傾向であり $(F(1,151)=3.11, p=.080)$, 男性顔の方 が再認成績が高かった。すなわち，顔刺激の向きを問わず， 男性参加者においてジェンダーバイアスが示された.

一方, false alarm 率については，参加者の性別×顔刺激の 性別の交互作用は有意ではなく $\left(F_{\mathrm{S}}<1\right)$, ジェンダーバイア スは示されなかった。

続いて，Aについては，参加者の性別×顔刺激の性別×顔 刺激の向きという二次の交互作用が有意傾向であったため

$(F(1,151)=2.88, p=.091)$ ，下位検定を行ったところ，女性参 加者の倒立顔において顔刺激の向きの単純・単純主効果が有 意であった $(F(1,302)=4.49, p=.035)$.つまり， hit 率における 分析結果とは異なり，女性参加者かつ倒立顔でジェンダーバ イアスが示されたことになる.

\section{考 察}

記憶指標の違いによって多少異なるものの，全体として結 果を概観すれば，本研究では，正立顔だけでなく，倒立顔に おいてもジェンダーバイアスが生じたものと考えられる.た とえば，Rhodes et al. (1989)では，正立顔に対しては人種バイ アスが生じる一方で，全体的処理が阻害される倒立顔を用い ると人種バイアスが消失することを示すことによって，知覚 的熟達要因の関与を指摘している. このロジックを援用すれ ば，本研究で倒立顔を用いてもジェンダーバイアスは消失し なかったことから，ジェンダーバイアスの生起には知覚的熟 達要因は関与していないと考えられる.

しかしながら, 本研究では, $A$ において先行研究の追試に あたる部分，たとえば，女性参加者の正立顔においてジェン ダーバイアスが示されていないため，上記の解釈も限定的な ものと考えなければならない.

\section{引用文献}

Lewin, C., \& Herlitz, A. (2002). Sex differences in face recognition: Women's faces make the difference. Brain and Cognition, 50(1), 121-128.

Rhodes, G., Brake, S., Taylor, K., \& Tan, S. (1989). Expertise and configural coding in face recognition. British Journal of Psychology, 80(3), 313-331.

Kuefner, D., Macchi Cassia, V., Picozzi, M., \& Bricolo, E. (2008). Do all kids look alike? Evidence for an other-age effect in adults. Journal of Experimental Psychology: Human Perception and Performance, 34(4), 811-817. 